\title{
Morphometric Identification, Gross and Histopathological Lesions of Eimeria Species in Japanese Quails (Coturnix coturnix japonica) in Zaria, Nigeria
}

\author{
H. A. Umar, ${ }^{1}$ I. A. Lawal, ${ }^{1}$ O. O. Okubanjo, ${ }^{1}$ and A. M. Wakawa ${ }^{2}$ \\ ${ }^{1}$ Department of Veterinary Parasitology and Entomology, Faculty of Veterinary Medicine, Ahmadu Bello University, \\ Zaria 2222, Nigeria \\ ${ }^{2}$ Department of Avian Medicine, Faculty of Veterinary Medicine, Ahmadu Bello University, Zaria 2222, Nigeria
}

Correspondence should be addressed to H. A. Umar; halilu_umar@yahoo.co.uk

Received 25 August 2014; Accepted 12 October 2014; Published 5 November 2014

Academic Editor: Vito Laudadio

Copyright (C) 2014 H. A. Umar et al. This is an open access article distributed under the Creative Commons Attribution License, which permits unrestricted use, distribution, and reproduction in any medium, provided the original work is properly cited.

\begin{abstract}
The objective of the study was to identify the species, gross and histopathological lesions of Eimeria in Japanese quails in Zaria. A total of 400 fresh faecal samples were collected and 10 quail birds were purchased from a quail farm. The faecal samples were processed using simple floatation technique. Oocysts shape indices of sporulated oocysts were determined. The intestines were observed for gross lesions and segments were analyzed using Giemsa stain and Haematoxylin and Eosin stain and then observed microscopically for the developmental stages of the parasite. Four species of Eimeria were identified in the study. Eimeria bateri of shape index of 1.36 conformed to the guidelines used while the other three Eimeria species with shape indices of 1.48, 1.03, and 1.40 were not confirmed. The main gross lesion seen was nonhaemorrhagic ballooning of the caeca. Intestinal scrapping smear revealed a developmental stage of the parasite (merozoites) in the jejunum. Histopathology also revealed a developmental stage (schizont) of the parasite in the caecum and desquamation of the epithelial lining with areas of necrosis. Further study is required using molecular techniques to properly identify the unknown species of Eimeria that were detected in the study.
\end{abstract}

\section{Introduction}

Quails are most susceptible to various diseases such as coccidiosis which is recognized as a serious parasitic disease problem limiting quail industry [1]. Quail production has become important in Nigeria. Descriptions of Eimeria date from the beginning of the last century, and ever since means for an appropriate characterization and identification of the species have been discussed. Several parameters can be used [2] and new methods have been developed [3-6]. Various species of Eimeria have been isolated from the different species of quails such as E. tsunodai, E. uzura, and E. bateri described from Japanese quails [7] and E. lophortygis and E. okanaganensis described from California quails, while $E$. crusti and E. oreortygis are described from mountain quail [8], E. conturnicis and E. bateri are described from grey quail [9], E. colini and E. lettyae are described from bob white quail [10], and also E. tahamensis is described from Arabian quail [11]. The natural infection of Eimeria in quails is characterized as subclinical because of the mild and nonspecific clinical signs. Nevertheless, coccidiosis is considered as an important disease because the endogenous stages of the parasites and a high number of oocysts in feces are associated with intestinal lesions [7]. Therefore, the objective of the study was to identify the species and report the gross and histopathological lesions of Eimeria in Japanese quails in Zaria, Nigeria.

\section{Materials and Methods}

2.1. Study Area. This study was carried out in Zaria located in Kaduna State, located within latitudes $11^{\circ} 7^{\prime}$ to $11^{\circ} 12^{\prime} \mathrm{N}$ and longitude $07^{\circ} 41^{\prime} \mathrm{E}$. It is a medium sized city with an estimated population of 408,198 [12]. It is divided administratively into Zaria and Sabon Gari LGAs [13]. It has an estimated land area 
TABLE 1: Morphological characteristics and speciation of Eimeria in Japanese quail.

\begin{tabular}{|c|c|c|c|c|c|c|c|c|}
\hline \multirow[b]{2}{*}{ Species } & \multicolumn{3}{|c|}{ Oocyst size $(\mu)$} & \multirow[b]{2}{*}{ Shape index } & \multirow[b]{2}{*}{ Morphology } & \multirow{2}{*}{$\begin{array}{l}\text { Polar } \\
\text { granule }\end{array}$} & \multirow[b]{2}{*}{ Oocyst wall } & \multirow{2}{*}{$\begin{array}{l}\text { Confirmed } \\
\text { species }\end{array}$} \\
\hline & $\begin{array}{c}\text { Length } \\
\text { (Mean } \pm \text { StE.) }\end{array}$ & $\begin{array}{c}\text { Width } \\
(\text { Mean } \pm \text { StE. })\end{array}$ & Range & & & & & \\
\hline (a) Eimeria spp. & $22.20 \pm 0.58$ & $16.38 \pm 0.42$ & $\begin{array}{l}(18.20-25.48) \\
(14.56-18.20)\end{array}$ & 1.36 & Subspherical & Present & Double & $\begin{array}{c}\text { Eimeria } \\
\text { bateri }\end{array}$ \\
\hline (b) Eimeria spp. & $22.36 \pm 1.67$ & $15.08 \pm 0.95$ & $\begin{array}{l}(14.56-25.48) \\
(10.92-18.20)\end{array}$ & 1.48 & Ovoid & Absent & Double & Unknown \\
\hline (c) Eimeria spp. & $16.64 \pm 1.08$ & $16.12 \pm 0.74$ & $\begin{array}{l}(14.56-21.84) \\
(14.56-18.20)\end{array}$ & 1.03 & Ellipsoidal & Absent & Double & Unknown \\
\hline (d) Eimeria spp. & $20.57 \pm 0.40$ & $14.74 \pm 0.56$ & $\begin{array}{l}(18.20-21.84) \\
(10.92-21.84)\end{array}$ & 1.40 & Subspherical & Absent & Double & Unknown \\
\hline
\end{tabular}

of about 300 square kilometers and it is approximated that about $40-75 \%$ of its working population derive their principal means of livelihood from agriculture [14]. Zaria which is located in the North Guinea Savannah zone of Nigeria has an annual ambient temperature, ranging between $18.0 \pm 3.7^{\circ} \mathrm{C}$ and $31.8 \pm 3.2^{\circ} \mathrm{C}$. The harmattan season (the cold-dry period of the year) lasts from November to February, while the hotdry season lasts from March to May and the rainy season lasts from June to October $[15,16]$.

2.2. Sample Collection, Handling, and Processing. Forty fresh faecal samples were collected using polythene bags. Ten live quail birds were also gotten from the farm. The samples were labeled and transported to the Helminthology Laboratory in the Department of Veterinary Parasitology and Entomology, Faculty of Veterinary Medicine, Ahmadu Bello University, Zaria. In the laboratory samples not examined immediately were refrigerated at $4^{\circ} \mathrm{C}$ to maintain the integrity of the oocyst [17].

2.3. Laboratory Examination. The faecal samples were examined for the presence of coccidia oocysts using the simple floatation technique as described by Urquhart et al. [18] .

Oocyst positive samples were diluted into $2.5 \%$ aqueous potassium dichromate $\left(\mathrm{K}_{2} \mathrm{Cr}_{2} \mathrm{O}_{7}\right)$ and kept in Petri dishes for sporulation at room temperature. After sporulation, oocysts were recovered by centrifugation with saturated sugar solution as described by Duszynski and Wilber [17] and used in subsequent analysis.

The shape indices (length/width) of the sporulated oocysts were determined by using the method for species identification as described by Harper and Penzorn [19].

The calculated oocysts shape index values were then compared with the standard diagnostic guide provided by Teixeira et al. [20] to determine the species encountered in the study.

2.4. Necropsy. The birds were euthanized and this was accomplished in accordance with guide for the care and use of laboratory animals [21].

Segments of the small intestine (duodenum, jejunum, and ileum) and large intestine (caeca) were taken for gross and histopathological studies.

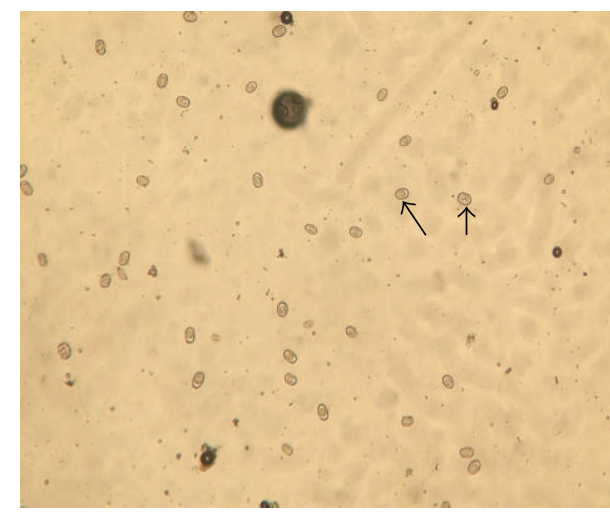

FIGURE 1: Numerous unsporulated Eimeria oocyst from quails using simple floatation technique $(\times 10)$.

The segments were examined macroscopically for gross lesions. Intestinal scraping smear was carried out to detect the presence of developmental stages of the parasite within the intestine using Giemsa stain as described by Dubey [22].

Histological examination was carried out to confirm the presence of the developmental stages of the parasites and pathological lesions within the small and large intestine using Haematoxylin and Eosin stain as described by Mitchell et al. [23].

2.5. Statistical Analysis. Oocysts measurements were analyzed using the software Excel (Microsoft) for mean and standard deviation.

\section{Results}

3.1. Oocyst Speciation. Table 1 shows the oocyst dimensions and morphological characteristics of different Eimeria species identified in the study. The Eimeria species encountered in the study were Eimeria bateri (Figure 2) and three other Eimeria species (Figures 3, 4, and 5) not covered by the diagnostic guidelines.

3.2. Gross and Histopathological Lesions. The fresh faecal sample was positive for Eimeria oocysts (Figure 1). The main gross pathology seen was the ballooning of the caeca which 


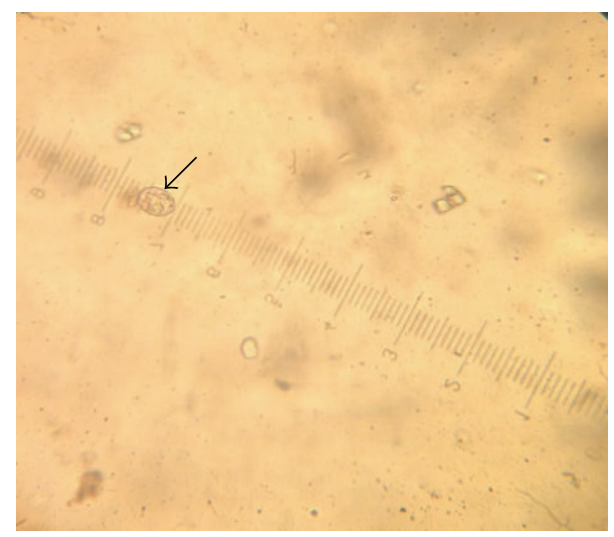

FIgURE 2: Subspherical Eimeria bateri oocyst with a polar granule using ocular micrometer $(\times 40)$.

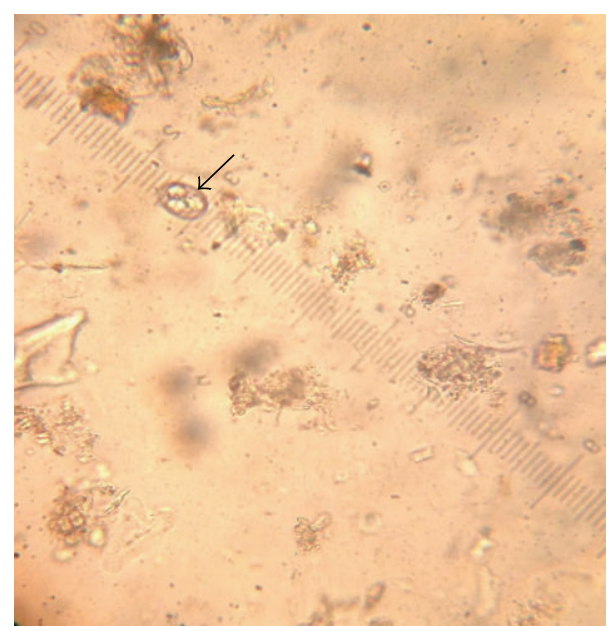

FIGURE 3: Ovoid Eimeria oocyst using ocular micrometer $(\times 40)$.

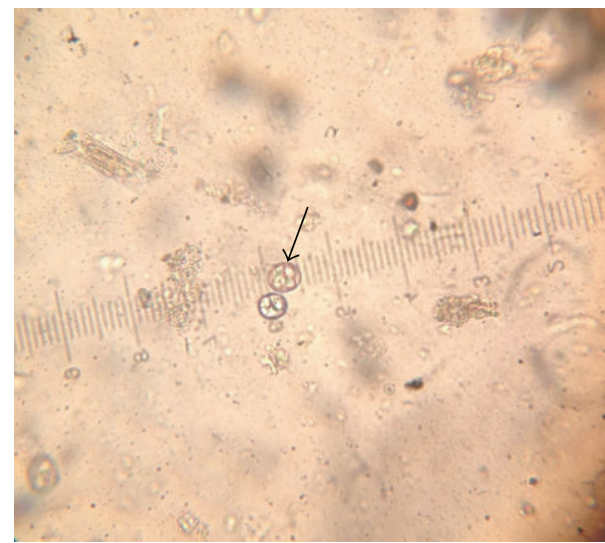

Figure 4: Ellipsoidal Eimeria oocyst using an ocular micrometer $(\times 40)$.

contains no bloody exudate in the lumen (Figure 6). Histopathologically, desquamation of intestinal mucosa was observed (Figure 9) and caecal necrosis (Figure 8). Developmental stages of the parasite especially the merozoites and schizont were seen in the intestinal epithelium (Figures 7, 8, and 9).

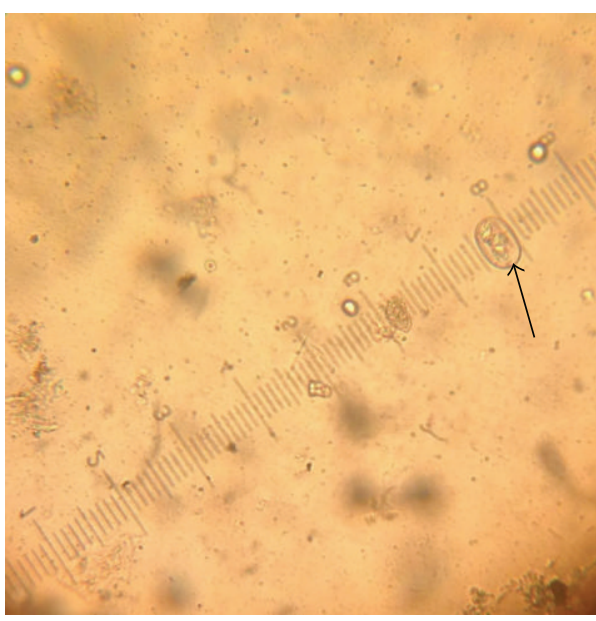

FIGURE 5: Subspherical Eimeria oocyst with no polar granule using ocular micrometer $(\times 40)$.

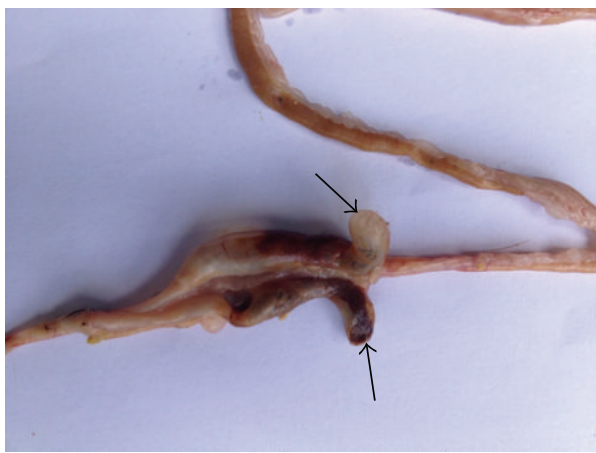

FIGURE 6: Ballooning of the caeca of a Japanese quail naturally infected with Eimeria bateri.

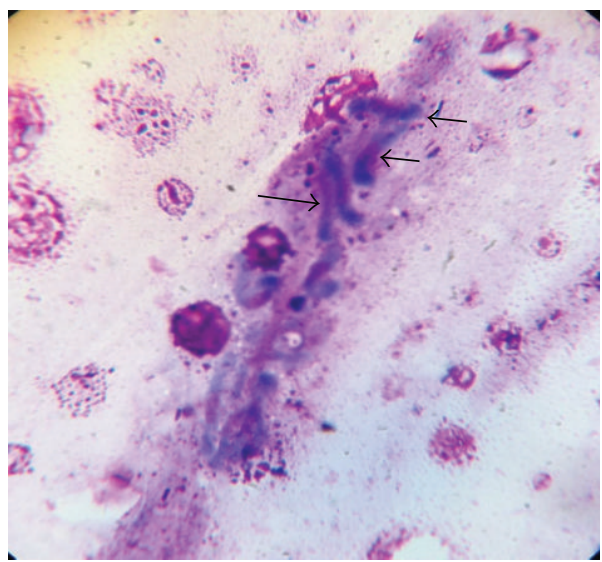

FIGURE 7: Jejunum of Japanese quail showing the developmental stage (merozoite) of Eimeria spp. in the epithelium using Giemsa stain $(\times 100)$ oil immersion.

\section{Discussion}

Quails are considered a branch of the modern poultry industry in Nigeria. The study showed that there were coccidia oocysts in the farm sampled from. In our study the identification of Eimeria species was done using the oocysts 


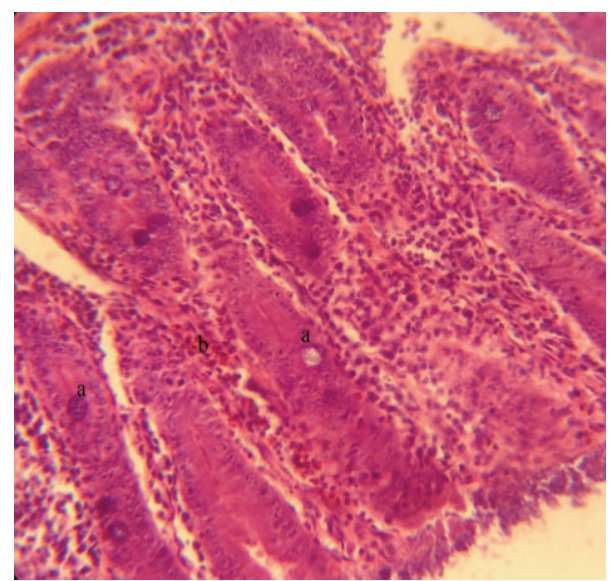

FIGURE 8: Histological section of the caecum showing the (a) developmental stage (schizont) of Eimeria spp. and (b) area of necrosis H\&E $(\times 40)$.

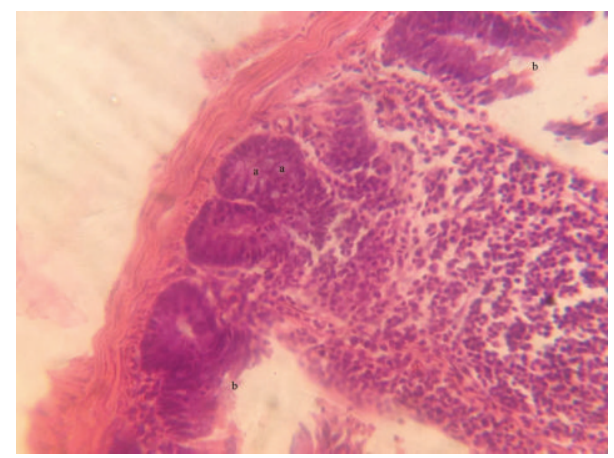

FIGURE 9: Histological section of duodenum showing the (a) developmental stage (schizonts) of Eimeria spp. and (b) desquamation of the epithelium $\mathrm{H} \& \mathrm{E}(\times 40)$.

morphometric technique. Four Eimeria species were identified from Japanese quails in the study. Eimeria bateri with shape index of 1.36 conformed to the guidelines of Teixeira et al. [20] and Mohammad [24]. The other three Eimeria species with shape indices of $1.48,1.03$, and 1.40 could not speciate as they do not conform to any of the given species by the above authors.

In spite of the shortcomings identified above, differences in morphology of the oocyst which were ovoid, subspherical, and ellipsoidal, presence and absence of polar granule can be observed. This means that other unidentified species of Eimeria exist in Zaria. Discrimination of Eimeria species using this technique has sort of limitations to be used as a single tool for diagnosis, meaning that results obtained with this method should be carefully interpreted $[25,26]$. This is because the measurements of the oocysts may undergo variations due to changes in metabolism of the parasites or birds and even in the value of the shape morphometric indices of the oocysts that may overlap leading to misleading conclusions regarding the species [27]. Despite the limitations of morphometric techniques, there are some reports that indicated that oocyst morphometry could also be a sensitive method for the discrimination of Eimeria species of poultry in field trials as it shows high degree of agreement with the molecular methods [28-31]. The use of molecular techniques is the most specific and rapid way of diagnosing Eimeria infection especially when it involves several species occurring concurrently [32-34]. However, in developing countries like Nigeria very few laboratories have the facilities and personnel to carry out these molecular techniques for routine diagnosis of coccidiosis. The study also showed that the gross lesions associated with Eimeria infection in Japanese quails were limited to mainly ballooning of the caeca. The only clinical signs observed were diarrhea. The reports of previous works seem to be at variance with the present observation as regards the pathogenicity of Eimeria in quails. Mazurkiewicz et al. [35] reported a wide range of clinical signs such as lack of appetite, ruffled feathers, uncoordinated movements, inhibition of laying, and loss of weight in naturally infected young and mature quails reared at the laboratory. In young Japanese quailsinfected with Eimeria bateri, mild loss of weight, anorexia, and softening of feces were observed and were considered mild and easy to overcome [36]. Tsunoda and Muraki [37] also reported low pathogenicity in Japanese quails experimentally infected with $1 \times 10^{5}$ oocysts of Eimeria uzura with signs limited to diarrhea and anemia with no mortality was reported. However, Ruff et al. [38] used pure and mixed cultures of $E$. uzura to infect quails and reported mortality, lower weight gain, and poor reproductive performance. Several factors such as environment, differences in the parasite strain, and management system may be responsible for the discrepancies in the observation of the various works. The findings from this study show that merozoites are the main endogenous stages of the parasites found in the small intestine and schizonts in the large intestine. The absence of other pathogenic stages such as the gametocytes means that the pathology of the infected quails will be mild. Histopathological lesions were located in the villi. These observations resemble those of Norton and Peirce [36], Mazurkiewicz et al. [35], and Tsutsumi [9] as regards the site of infection. Desquamation of epithelial lining and caecal necrosis were also observed in the study.

In conclusion, four Eimeria species were identified in the study, only Eimeria bateri speciated as it conformed to the guideline used. Due to the limitations of speciation using the oocysts morphometry technique, there is the need for further studies to be carried out using molecular techniques to properly identify the unknown species of Eimeria which were detected in the study. The study also showed that the gross and histopathological changes in intestinal tract pointed to the serious effect of Eimeria species in quails. This observation has an important value since there is a paucity of information on the pathogenicity of Eimeria spp. in quails.

\section{Conflict of Interests}

The authors declare that there is no conflict of interests regarding the publication of this paper. 


\section{References}

[1] S. Seok, J. Park, S. Cho, M. Baek, H. Lee, and D. Kim, "Coccidian (Eimeria $s p p$ ) in small intestine of Japanese quail (Coturnix coturnix japonica)," Korean Journal of Laboratory Animal Science, vol. 19, no. 2, pp. 90-91, 2003.

[2] P. L. Long and L. P. Joyner, "Problems in the identification of species of Eimeria," Journal of Protozoology, vol. 31, no. 4, pp. 535-541, 1984.

[3] J. Kucera and M. Reznický, "Differentiation of species of Eimeria from the fowl using a computerized image-analysis system.", Folia Parasitologica, vol. 38, no. 2, pp. 107-113, 1991.

[4] A. Daugschies, S. Imarom, and W. Bollwahn, "Differentiation of porcine Eimeria spp. by morphologic algorithms," Veterinary Parasitology, vol. 81, no. 3, pp. 201-210, 1999.

[5] A. Gruber and S. Fernandez, "Recentes avanços na biologia molecular de protozoários do gênero Eimeria," in II Simpósio Internacional sobre coccidiose aviária, pp. 9-21, Foz do Iguaçu, Brazil, 1999.

[6] M. J. S. Pereira, A. H. Fonseca, and C. W. G. Lopes, "Regressão linear na caracterização de variações morfométricas em coccidia," Revista Brasileira de Parasitologia Veterinária, vol. 10, pp. 75-78, 2001.

[7] M. Teixeira and C. W. G. Lopes, "Species of the genus Eimeria (Apicomplexa : Eimeriidae) from Japanese quails (Coturnix japonica) in Brazil and Eimeria fluminensis for the preoccupied Eimeria minima of this quail," Revista Brasileira de Ciências Veterinárias, vol. 9, pp. 53-56, 2002.

[8] D. W. Duszynski and R. J. Gutiérrez, "The coccidia of quail in the United States," Journal of Wild Diseases, vol. 17, no. 3, pp. 371-379, 1981.

[9] Y. Tsutsumi, “Eimeria tsunodai sp. nov. (protozoa: Eimeriidae). A caecal coccidium of Japanese quails (Coturnix coturnix japonica)," The Japanese journal of veterinary science, vol. 34, no. 1, pp. 1-9, 1972.

[10] M. D. Ruff, "Life cycle and biology of Eimeria lettyae sp. n. (Protozoa: Eimeriidae) from the Northern bobwhite, Colinus virginianus (L.)," Journal of Wildlife Diseases, vol. 21, no. 4, pp. 361-370, 1985.

[11] M. A. Amoudi, "Eimeria tahamensis N. sp. (Apicomplexa: Eimeriidae) from the Arabian quail (Coturnix delegorguei arabica)," Journal of Protozoology, vol. 34, no. 4, pp. 455-456, 1987.

[12] National Population Commission (NPC), "Location of Zaria," in The Latitude and Longitude of Zaria Zone in Kaduna State, Nigeria, pp. 26-35, 2006.

[13] Ministry of Economic Development, Kaduna State Statistical Year Book, Statistics Division, Ministry of Economic Development, Kaduna, Nigeria, 1996.

[14] Ahmadu Bello University, Zaria Master Plan, Department of Urban and Regional Planning, ABU Zaria, Zaria, Nigeria, 2000.

[15] J. O. Ayo, J. A. Obidi, and P. I. Rekwot, "Effects of heat stress on the well-being, fertility and hatchability of chicken in the Northern Guinea Savannah zone of Nigeria: a review," ISRN Veterinary Science, vol. 2011, Article ID 838606, 10 pages, 2011.

[16] T. Dzenda, J. O. Ayo, C. A. M. Lakpini, and A. B. Adelaiye, "Seasonal, sex and live weight variations in feed and water consumptions of adult captive African Giant rats (Cricetomys gambianus, Waterhouse-1840) kept individually in cages," Journal of Animal Physiology and Animal Nutrition, vol. 97, no. 3, pp. 465-474, 2013.
[17] D. W. Duszynski and P. G. Wilber, "A guideline for the preparation of species descriptions in the Eimeriidae," Journal of Parasitology, vol. 83, no. 2, pp. 333-336, 1997.

[18] G. M. Urquhart, J. Armour, J. L. Dunkan, A. M. Dunn, and F. W. Jennings, Veterinary Parasitology, Longman, Essex, UK, 1987.

[19] C. K. Harper and B. L. Penzhorn, "Occurrence and diversity of coccidia in indigenous, Saanen and crossbred goats in South Africa," Veterinary Parasitology, vol. 82, no. 1, pp. 1-9, 1999.

[20] M. Teixeira, F. W. L. Teixeira, and C. W. G. Lopes, "Coccidiosis in Japanese quails (Coturnix japonica) characterization of a naturally occurring infection in a commercial rearing farm," Revista Brasileira de Ciência Avícola, vol. 6, no. 2, pp. 129-134, 2004.

[21] National Research Council, Guide for the Care and Use of Laboratory Animals, The National Academies Press, Washington, DC, USA, 1996.

[22] J. P. Dubey, Toxoplasmosis of Animals and Humans, CRC Press, Boca Raton, Fla, USA, 2nd edition, 2009.

[23] R. S. Mitchell, V. Kumar, A. K. Abbas, and N. Fausto, Robbins Basic Pathology, chapter 11, Saunders, Philadelphia, Pa, USA, 2003.

[24] N. H. Mohammad, "A study on the pathological and diagnosis of Eimeria species infection in Japanese quail," Basrah Journal of Veterinary Research, vol. 11, no. 1, pp. 318-333, 2012.

[25] W. G. Woods, G. Richards, K. G. Whithear, G. R. Anderson, W. K. Jorgenses, and R. B. Gasser, "High-resolution electrophoretic procedures for the identification of five Eimeria species from chickens and detection of population variation," Electrophoresis, vol. 21, pp. 3558-3563, 2000.

[26] G. J. López, J. Figuerola, and R. Soriguer, “Time of day, age and feeding habits influence coccidian oocyst shedding in wild passerines," International Journal for Parasitology, vol. 37, no. 5, pp. 559-564, 2007.

[27] X. M. Sun, W. Pang, T. Jia et al., "Prevalence of Eimeria species in broilers with subclinical signs from fifty farms," Avian Diseases, vol. 53, no. 2, pp. 301-305, 2009.

[28] A. T. Terra, P. S. Costa, P. C. Figueiredo, and E. C. Q. Carvalho, "Frequency of species of the genus Eimeria in broilers slaughtered industrially in the municipality of Monte Algre do Sul, State of Sao Paulo," Revista Brasileira de Parasitologia Veterinaria, vol. 10, no. 2, pp. 87-90, 2001.

[29] F. C. Luchese, M. Perin, R. S. Aita, V. D. Mottin, M. B. Molento, and S. G. Monteiro, "Prevalence of Eimeria species in industrial and alternative bred chicken," Brazilian Journal of Veterinary Research and Animal Science, vol. 44, no. 2, pp. 81-86, 2007.

[30] A. Haug, A.-G. Gjevre, P. Thebo, J. G. Mattsson, and M. Kaldhusdal, "Coccidial infections in commercial broilers: epidemiological aspects and comparison of Eimeria species identification by morphometric and polymerase chain reaction techniques," Avian Pathology, vol. 37, no. 2, pp. 161-170, 2008.

[31] F. S. Carvalho, A. A. Wenceslau, M. Teixeira, J. A. Matos Carneiro, A. D. B. Melo, and G. R. Albuquerque, "Diagnosis of Eimeria species using traditional and molecular methods in field studies," Veterinary Parasitology, vol. 176, no. 2-3, pp. 95100, 2011.

[32] S. Fernandez, A. H. Pagotto, M. M. Furtado, Â. M. Katsuyama, A. M. B. N. Madeira, and A. Gruber, "A multiplex PCR assay for the simultaneous detection and discrimination of the seven Eimeria species that infect domestic fowl," Parasitology, vol. 127, no. 4, pp. 317-325, 2003. 
[33] A. Haug, P. Thebo, and J. G. Mattsson, "A simplified protocol for molecular identification of Eimeria species in field samples," Veterinary Parasitology, vol. 146, no. 1-2, pp. 35-45, 2007.

[34] V. Vrba, D. P. Blake, and M. Poplstein, "Quantitative real-time PCR assays for detection and quantification of all seven Eimeria species that infect the chicken," Veterinary Parasitology, vol. 174, no. 3-4, pp. 183-190, 2010.

[35] M. Mazurkiewicz, D. Podlewska, and Z. Wachnik, "Kokcydioza u przepiórek japonskich," Medycyna Weterynaryjna, vol. 23, pp. 536-537, 1967.

[36] C. C. Norton and M. A. Peirce, "The life cycle of Eimeria bateri (Protozoa, Eimeriidae) in the Japanese quail Coturnix coturnix japonicum," The Journal of Protozoology, vol. 18, no. 1, pp. 57-62, 1971.

[37] K. Tsunoda and Y. Muraki, "A new coccidium of Japanese quails: Eimeria uzura sp. nov," The Japanese Journal of Veterinary Science, vol. 33, no. 5, pp. 227-235, 1971.

[38] M. D. Ruff, J. M. Fagan, and J. W. Dick, "Pathogenicity of coccidia in Japanese quail (Coturnix coturnix japonica)," Poultry Science, vol. 63, no. 1, pp. 55-60, 1984. 

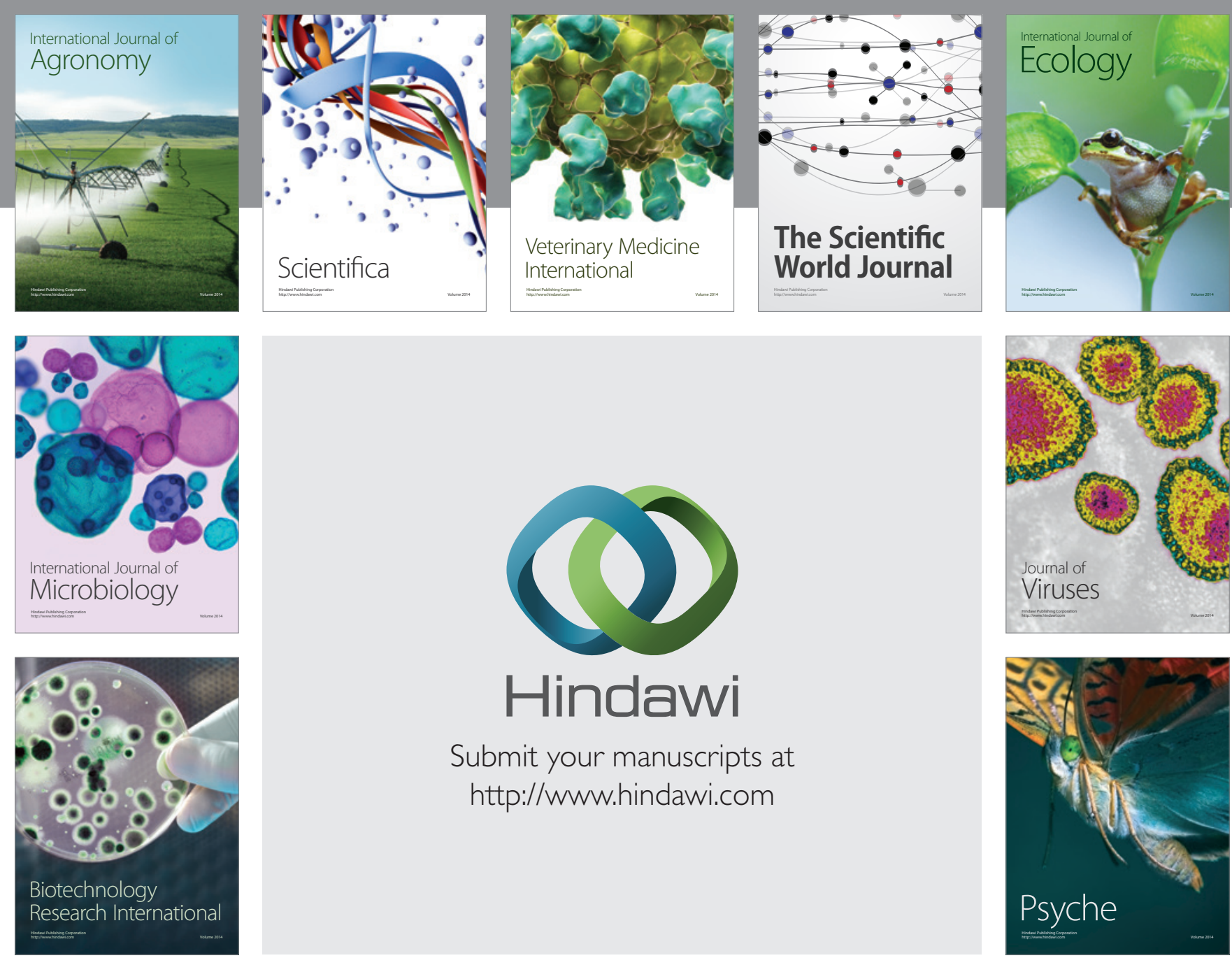

Submit your manuscripts at http://www.hindawi.com
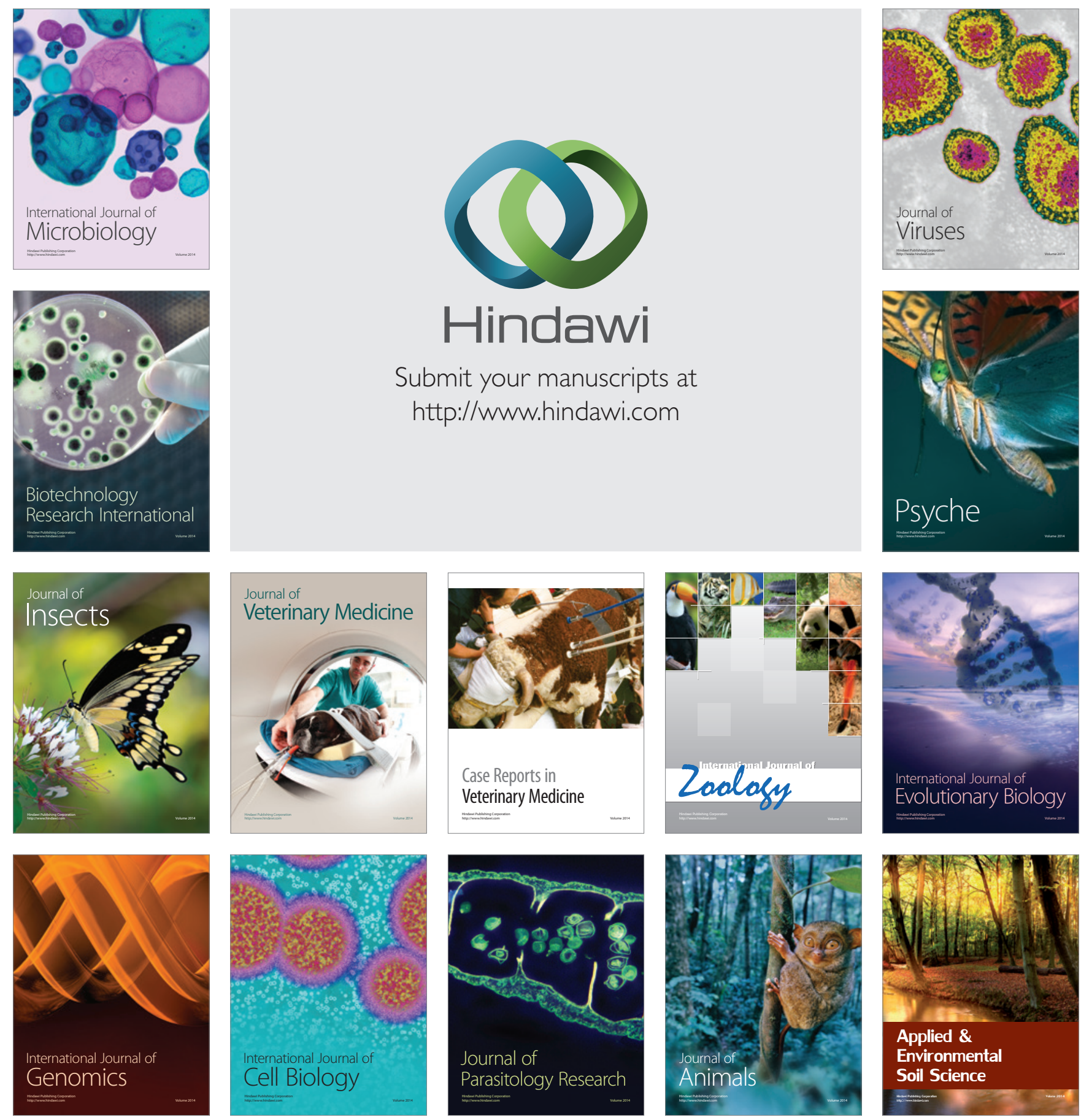